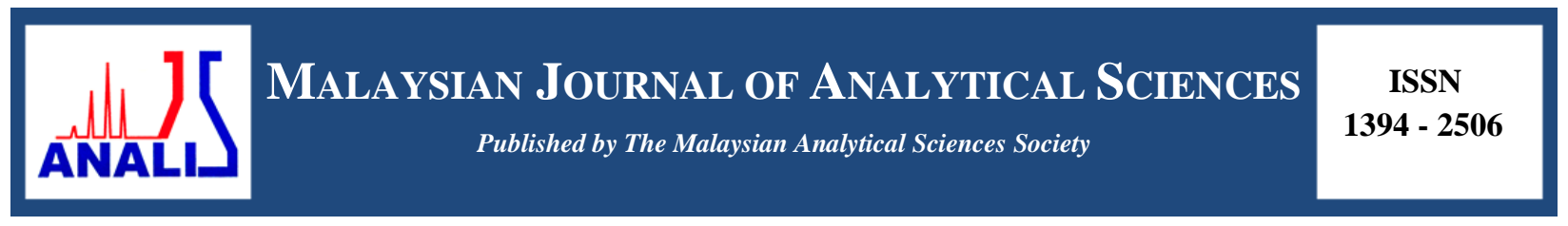

\title{
PREPARATION AND CHARACTERIZATION OF IMPROVED HYDROPHILIC POLYETHERSULFONE/REDUCED GRAPHENE OXIDE MEMBRANE
}

\author{
(Penyediaan dan Pencirian Penambahkaikan Hidrofilik Membran Polietersulfon/Grafin Oksida \\ Terturun)
}

\author{
Madzlan Aziz ${ }^{1 *}$, Nur Fatihah Tajul Arifin ${ }^{2}$, Woei-Jye Lau ${ }^{1}$ \\ ${ }^{1}$ Advanced Membrane Technology Centre, \\ ${ }^{2}$ Department of Chemistry, \\ Faculty of Science, Universiti Teknologi Malaysia, \\ 81310 Johor Bahru, Johor, Malaysia \\ *Corresponding author: madzlan@utm.my
}

Received: 25 October 2017; Accepted: 22 January 2019

\begin{abstract}
Polyethersulfone (PES)/reduced graphene oxide ( $\mathrm{rGO}$ ) membrane was prepared by phase inversion method for water treatment. Graphene oxide (GO) was obtained via modified Hummer's method and reduced to rGO where $\mathrm{NaBH}_{4}$ was chosen as a reducing agent. FTIR was used to investigate functional groups left on rGO after reduction process. The FTIR peak at $1718 \mathrm{~cm}^{-1}$, attributed to the carbonyl $(\mathrm{C}=\mathrm{O})$ group, was absent after $\mathrm{GO}$ was reduced. Interlayer spacing of GO and rGO were obtained using XRD. It was found that the interlayer spacing of GO was reduced from 7.87 to $3.68 \AA$ after reduction process due to the removal of some of the functional groups from the material. The membrane cross section showed that addition rGO increase the length of finger-like pores as compared to neat PES when it is observed under SEM. It was observed that the membrane hydrophilicity is enhanced as the contact angle of PES reduced from $69.70^{\circ}$ to $32.99^{\circ}$ when rGO 24 hours was introduced into the polymer matrix. The highest pure water flux obtained was $174.29 \mathrm{~L} / \mathrm{m}^{2} \mathrm{~h}$. The membranes showed significant enhancement when rGO was used in the polymer matrix.
\end{abstract}

Keyword: polyethersulfone, phase inversion method, modified Hummer's method, reduced graphene oxide

Abstrak

Membran polietersufon (PES)/grafin oksida terturun (rGO) telah dihasilkan melalui kaedah fasa terbalik untuk rawatan air. Grafin oksida (GO) dihasilkan menerusi kaedah Hummer terubahsuai dan diturunkan kepada rGO menggunakan $\mathrm{NaBH}_{4}$ sebagai ejen penurunan. FTIR digunakan untuk menyiasat kumpulan berfungsi yang hadir pada rGO selepas proses penurunan. Puncak FTIR pada $1718 \mathrm{~cm}^{-1}$ yang menunjukkan kumpulan karbonil $(\mathrm{C}=\mathrm{O})$ tidak hadir selepas GO terturun. Jarak antara lapisan GO dan rGO telah dikaji menggunakan XRD. Didapati jarak antara lapisan GO berkurang daripada $7.87 \AA$ ke $3.68 \AA$ selepas proses penurunan kerana sebilangan kumpulan berfungsi telah terkeluar dari bahan. Keratan rentas membran menunjukkan bahawa penambahan rGO meningkatkan panjang liang seperti jejari berbanding PES asli apabila dilihat menggunakan SEM. Didapati bahawa sifat hidrofilik membran telah dipertingkatkan kerana sudut sentuh air PES telah berkurang dari $69.70^{\circ}$ kepada $32.99^{\circ}$ apabila rGO 24 jam ditambah ke dalam matriks polimer. Bacaan fluks air tulen tertinggi ialah $174.29 \mathrm{~L} / \mathrm{m}^{2} \mathrm{~h}$. Membran menunjukkan perubahan ketara apabila rGO digunakan di dalam matriks polimer.

Kata kunci: polietersulfon, kaedah fasa terbalik, kaedah Hummer terubahsuai, grafin oksida terturun 


\section{Madzlan et al: PREPARATION AND CHARACTERIZATION OF IMPROVED HYDROPHILIC \\ POLYETHERSULFONE/REDUCED GRAPHENE OXIDE MEMBRANE}

\section{Introduction}

Recently, study has claimed that polyethersulfone (PES) has great membrane-forming and excellent physicochemical properties which lead it to be used widely as a membrane in water treatment [1] such as in microfiltration, ultrafiltration and nanofiltration [2]. PES is a thermally stable and has excellent mechanical and chemical properties [3]. However, PES suffers from fouling due to its' hydrophobic characteristics [3] that will affect the performance of the membrane [4]. Thus, it is suggested that PES to undergo several modification to overcome the fouling problem such as blending with amphiphilic polymer [1], blending with hydrophilic polymers [5], grafting with hydrophilic monomer or blending with inorganic nanoparticles [4]. However, study stated that blending with hydrophilic material is one of the most promising method to enhance the properties of PES [6].

Graphene and its' derivatives received a lot of attentions in many fields which includes electronics, mechanics and water treatment [7]. This is because of its high surface area [4], excellent electrical and thermal conductivity as well as outstanding mechanical properties [8]. By forming interfacial bonding with polymer matrix, graphene promises that it can improve the physicochemical properties of polymers [9]. Nevertheless, pristine graphene is found to agglomerate during the formation process of homogeneous composites. Therefore, it is suggested that graphene need to undergo several modifications to overcome this problem [10]. For instance, graphene oxide (GO) which can be formed via modified Hummer's method is the most favorable material to be added into the polymer matrix as it can improve the membrane performance [4]. Besides that, GO/polymer composites able to improve the mechanical strength of the polymer [11].

For instance, study conducted by Lee and colleague [12] shows that addition of GO in polysulfone (PSf) able to improve the mechanical strength and hydrophilicity of the membrane. Besides that, Jin and coworkers [13] claimed that addition of GO increased the porosity of the membrane because large pores were observed. In addition, the mechanical strength and thermal stability become better. GO also able to form a good miscibility with PES and enhanced the hydrophilicity as the contact angle reduced from $70.8^{\circ}$ (neat PES) to 58.4 (GO/PES). Based on the literature review, there are many studies that have been conducted using GO. However, reports on reduced graphene oxide (rGO) in polymer membrane is still very few. Through reduction process, some of the functional groups will be eliminated [14]. rGO (Figure 1) can form interaction with polymer and improve the performance of the membrane as there are still oxygen functional group left after reduction process [15]. Therefore, the objective in study is to prepare rGO/PES composite membrane and to analyze the effect of addition of rGO towards the membrane hydrophilicity.

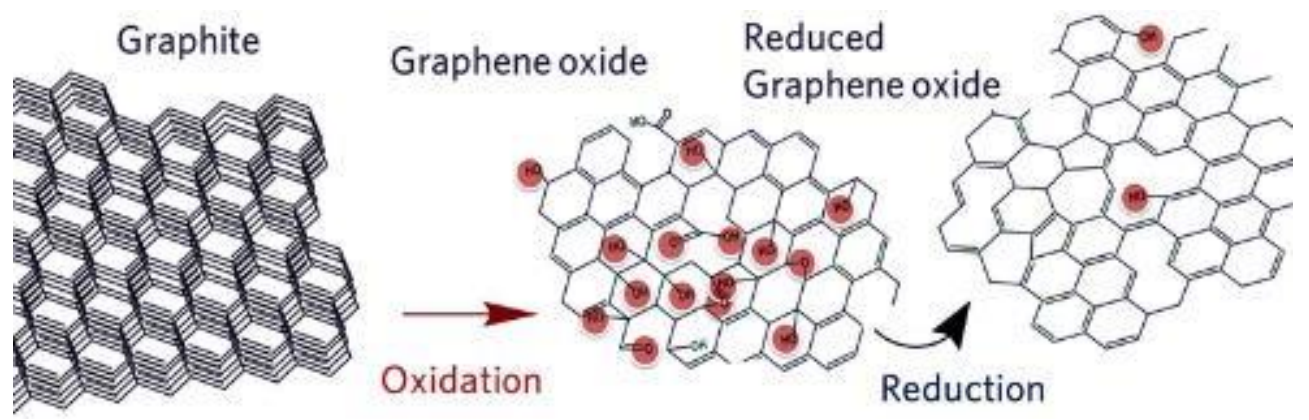

Figure 1. Chemical reaction of graphite to rGO [16]

\section{Study area}

PES was chosen as a polymer host because it is used extensively in water treatment [17]. To reduce $\mathrm{GO}, \mathrm{NaBH}_{4}$ was chosen as a reductant because it is a strong reducing agent [18] and environmental friendly [19]. This research will include the effect of reduction time towards GO and its compatibility with polymer composites. Firstly, the GO was obtained by oxidation of graphite via modified Hummer's method. Then, it was reduced through chemical reduction method. The reduction time was in the range of $8-32$ hours to elucidate the effect of reduction time on GO. Then, it was mixed with PES to study the compatibility with polymer composites. ATR-FTIR was used to study the 
functional groups that exist on the surface of rGO. The morphology of the GO and rGO were characterized using FESEM. Interlayer spacing of GO and rGO were studied using XRD. Meanwhile, contact angle was used to investigate the hydrophilicity of the membrane. On the other hand, SEM was chosen to observe the membrane cross-section and a cross-flow filtration system was used to evaluate the water flux.

\section{Materials and Methods}

GO was produced via modified Hummer's method. An amount of $4 \mathrm{~g}$ graphite powder was added into $100 \mathrm{~mL}$ of concentrated $\mathrm{H}_{2} \mathrm{SO}_{4}$ and followed by the slowly addition of $4 \mathrm{~g}$ of $\mathrm{NaNO}_{3}$. This was then followed by a slow addition of $12 \mathrm{~g}$ of $\mathrm{KMnO}_{4}$ under stirring condition and the temperature of the mixture was maintained below $10{ }^{\circ} \mathrm{C}$ in ice bath. The mixture was stirred at $35{ }^{\circ} \mathrm{C}$ for 30 minutes before $100 \mathrm{~mL}$ of deionized water was added to the mixture and a yellowish brown solution was formed. The mixture was stirred again for 30 minutes at $95{ }^{\circ} \mathrm{C}$. Lastly, $600 \mathrm{~mL}$ of distilled water, $20 \mathrm{~mL}$ of $30 \% \mathrm{H}_{2} \mathrm{O}_{2}$ aqueous solution and $100 \mathrm{~mL}$ of $10 \mathrm{wt} . \% \mathrm{HCl}$ were added after bright yellow color with bubbles appeared in the solution. The mixture was centrifuged and washed with deionized water to expel metal ion and acid until neutral $\mathrm{pH}$ was obtained. GO film that produced was dried in an oven for 12 hours at $60{ }^{\circ} \mathrm{C}$ [20]. To obtain rGO, GO was reduced using sodium borohydride $\left(\mathrm{NaBH}_{4}\right)$ via chemical reduction. Firstly, $0.8 \mathrm{~g}$ of GO was sonicated in $50 \mathrm{~mL}$ of water for 30 minutes. $\mathrm{NaBH}_{4}$ solution was prepared and the $\mathrm{pH}$ value was adjusted with $\mathrm{NaOH}$ to $\mathrm{pH} 12$ to prevent any occurring hydrolysis. After half an hour, $\mathrm{NaBH}_{4}$ solution was added drop-wise into GO solution and the solution was heated at $80^{\circ} \mathrm{C}$ for 8 hours with continuous stirring. After finishing hours, the mixture was filtered out via vacuum filtration and washed with $\mathrm{EtOH}$ and distilled water for several times. The product was dried in an oven at $70{ }^{\circ} \mathrm{C}$ for 24 hours to obtain reduced graphene oxide. The procedure was repeated with different reduction time $(8,16,24$ and 32 hours) [21].

Membrane was casted by using phase inversion method. PES (20 wt.\%) and PVP (1\%) were dispersed in NMP at $60{ }^{\circ} \mathrm{C}$ for 24 hours to obtain homogeneous solution. rGO-8h $(0.5 \mathrm{wt} . \%)$ was dispersed and sonicated in NMP for 30 minutes. Then, with the aid of continuous stirring the solution was mixed together for 24 hours at $60{ }^{\circ} \mathrm{C}$. After that, the mixture was casted on a clean glass plate. The glass plate was immersed into non-solvent (water) bath [11]. It was left until the phase inversion method is completed which is after the membrane get separated from glass plate. Finally, the membrane was peeled and washed. The membrane was dried at room temperature for 24 hours [4]. The method was repeated with GO, rGO-16h, rGO-24h, and rGO-32h.

\section{Results and Discussion}

Figure 2 shows the FT-IR spectrum of GO and rGO. Figure 2(a) shows that there are peaks around $3195 \mathrm{~cm}^{-1}$ and $1718 \mathrm{~cm}^{-1}$ which indicates that hydroxyl $(-\mathrm{OH})$ and carbonyl $(\mathrm{C}=\mathrm{O})$ groups exist on the surface of $\mathrm{GO}$ respectively. Intense peak at $1620 \mathrm{~cm}^{-1}$ shows bending mode of water molecules. Epoxy group exist on GO as there is peak at $1224 \mathrm{~cm}^{-1}$ and vanishes during the reduction process [22]. Besides that, some of the oxygenated functional groups have been removed from the surface of GO through the reduction process [23]. When GO is reduced, it is clearly shown that there are no peaks can be found at $1718 \mathrm{~cm}^{-1}$ which indicates the $\mathrm{C}=\mathrm{O}$ groups have been eliminated. Figure 2(e) indicates that there is C-H asymmetric stretching vibration mode $\left(2919 \mathrm{~cm}^{-1}\right)$ when $\mathrm{GO}$ is reduced for 8 hours [24]. Supposedly, as GO is being reduced many of $-\mathrm{OH}$ groups have been reduced. However, the $-\mathrm{OH}$ peak became more intense and this might be due to the fact that $\mathrm{NaBH}_{4}$ reduction would form residual hydroxyl functional groups when GO is reduced for 32 hours (Figure 2(b)) [25]. Overall, peak in the range of $1300-1450$ $\mathrm{cm}^{-1}$ indicates tertiary alcohol bending [22]. Meanwhile, peak around $1636-2655 \mathrm{~cm}^{-1}$ shows the deformation vibration of $-\mathrm{OH}$ groups [24]. 


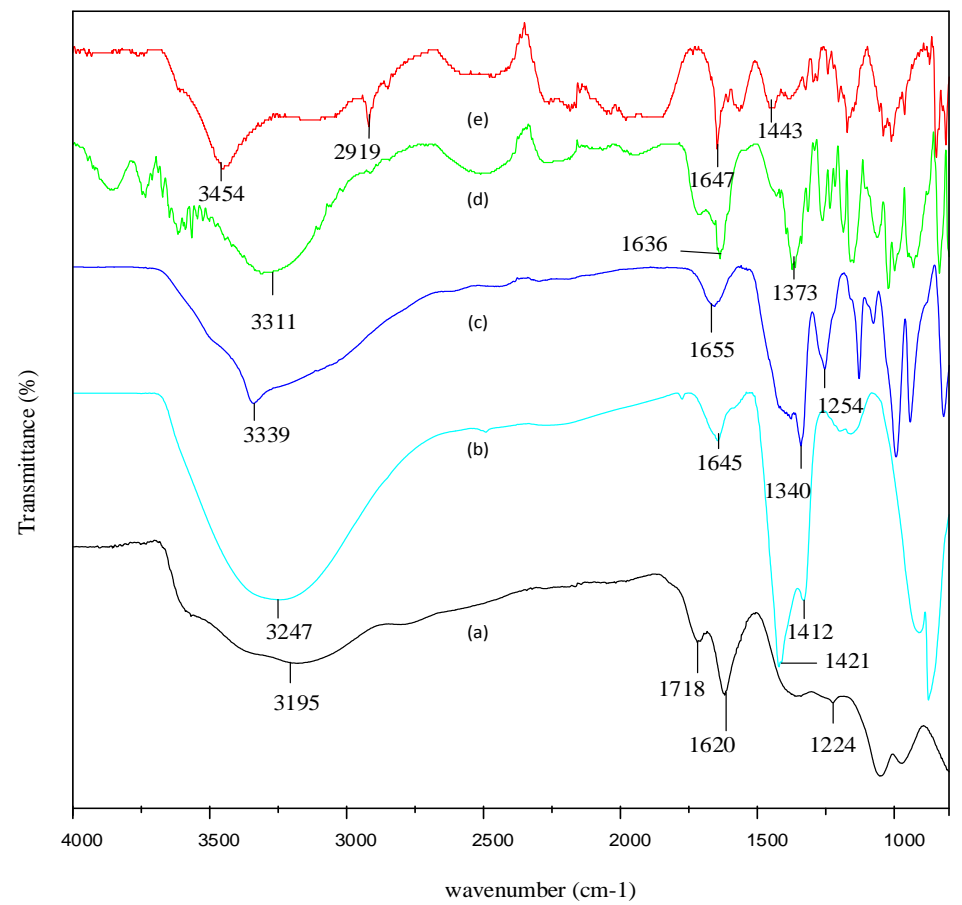

Figure 2. FT-IR spectrum of (a) GO (b) rGO-32h (c) rGO-24 h (d) rGO-16 h (e) rGO-8h

Figure 3 shows the XRD spectrum of (a) graphene oxide and (b) reduced graphene oxide. Based on Figure 3(a) it shows that there is an intense peak on $2 \theta=11.23^{\circ}$ which corresponds to the diffraction of GO plane (002). On the other hand, rGO (b) with index number of (002) indicates a broad spectrum at $2 \theta=24.16^{\circ}$. From this result, the interlayer spacing of GO and rGO are calculated by using Bragg's Law, $\lambda=2 d \sin \theta$ where $\lambda$ is the wavelength of the X-ray beam, $d$ is the interlayer spacing, and $\theta$ is the diffraction angle. It is found that the interlayer spacing of GO is $7.87 \AA$. This result may be explained by the fact that, expansion on graphene oxide occurred as oxygen functional groups attached on the surface of the material $[15,26]$. Besides that, the oxidation process has broken the $\pi-\pi$ van der Waals bond between the lamella thus increasing the interlayer spacing [27]. Meanwhile, the interlayer spacing of rGO is $3.68 \AA$ because most of the functional groups are removed during the reduction process [25].

\section{$11.23^{\circ}$}

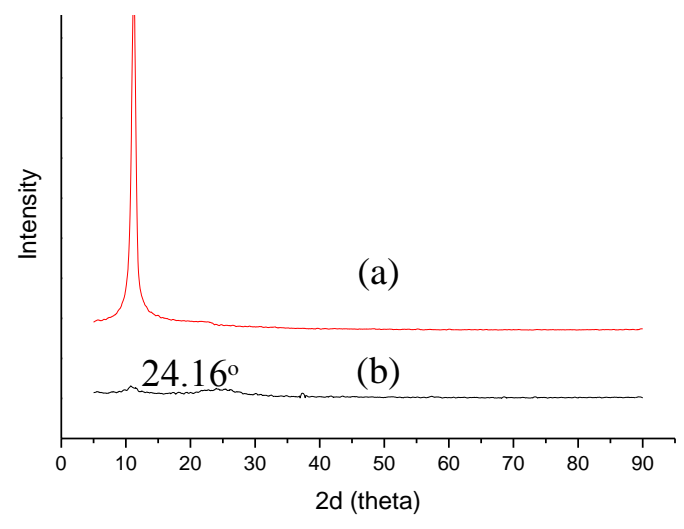

Figure 3. XRD spectrum of (a) graphene oxide (b) reduced graphene oxide 
Figure 4 shows the morphology of GO and rGO. Based on Figure 4 (a), GO exhibits wrinkles on its surface of $[27,28]$. The wrinkles will contribute to the conducting characteristics. Furthermore, the formation of the wrinkles and crumples like structure might be due to the existence of $\mathrm{H}_{2} \mathrm{O}$ molecules and hydroxyl or carboxyl groups [30]. In addition, the formation of wrinkles on the surface of GO means that the $\mathrm{sp}^{2}$-hybridized structure of the stacked graphene sheets has broken up [8]. Figure $4(\mathrm{~b}-\mathrm{e})$ shows that the surface of rGO are rougher and aggregated in disordered solid than GO. These results are likely to be related to the aggregation of rGO due to the strong van der Waals forces [29].
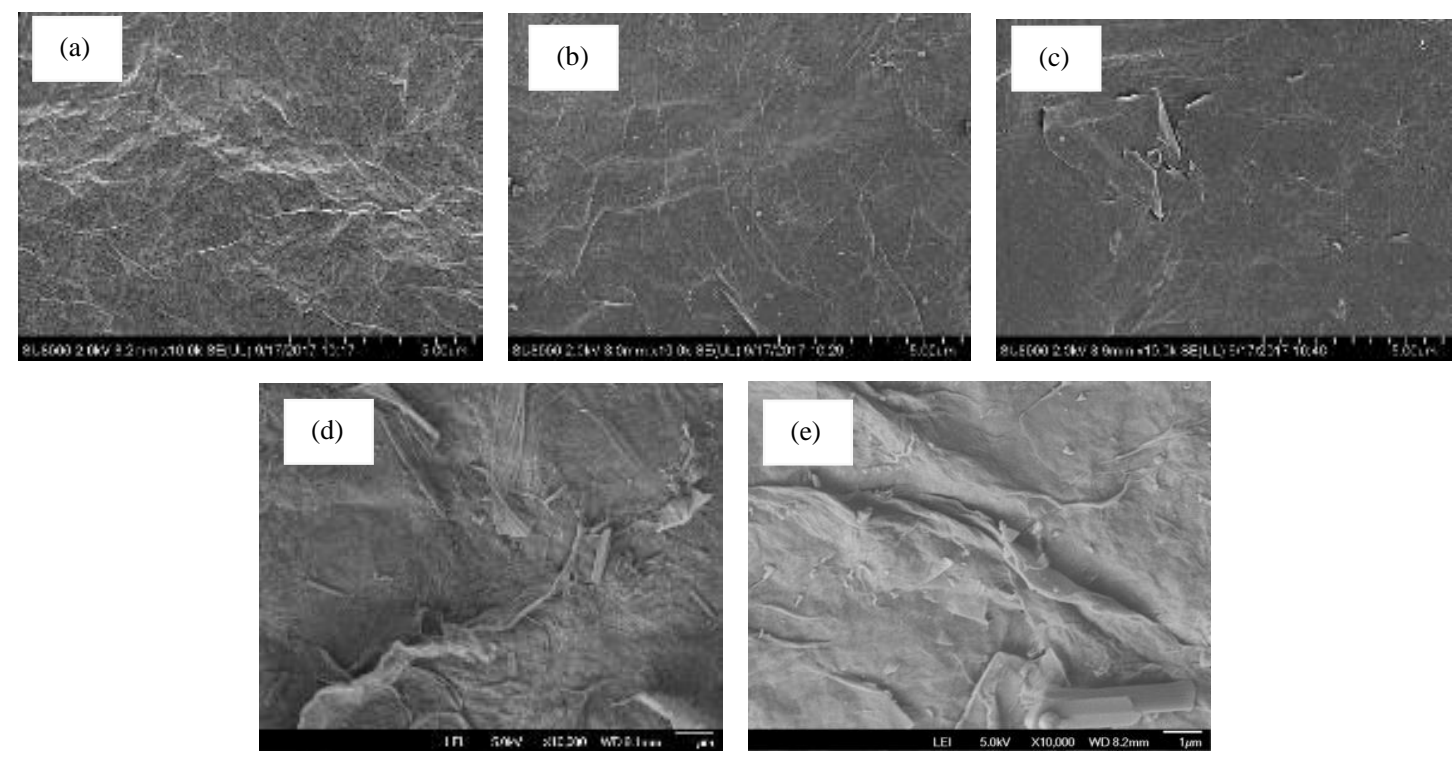

Figure 4. Morphology of (a) GO (b) rGO-8h (c) rGO-16h (d) rGO-24h (e) rGO-32h under 10000x magnification

The membrane cross section (Figure 5) shows a typical structure where it contain asymmetric porous structure with a dense skin top-layer followed by a finger-like porous sub-layer [4]. The cross section shows that the finger-like pore does not contain any trace of GO inside the membrane. Even as this happened, it does not mean that the nanomaterials are absent in the polymer matrix. This is because, the size of the nanomaterial is small and is not visible when it is observed using SEM [31]. The finger-like porous sub-layer increased when 0.5\% GO (Figure 5(b)) was added into the membrane. This is because, the hydrophilic characteristic of GO leads to fast exchange of solvent and non-solvent during the phase inversion process which leads to extended porosity. GO is also able to induce pores on the skin top layer. After the addition of $0.5 \% \mathrm{rGO}$, denser pore can be observed. Interestingly, as the reduction time of GO increased the pore density increased. However, the finger-like pores of the membranes are connected continuously with the finger-like sublayer [11].
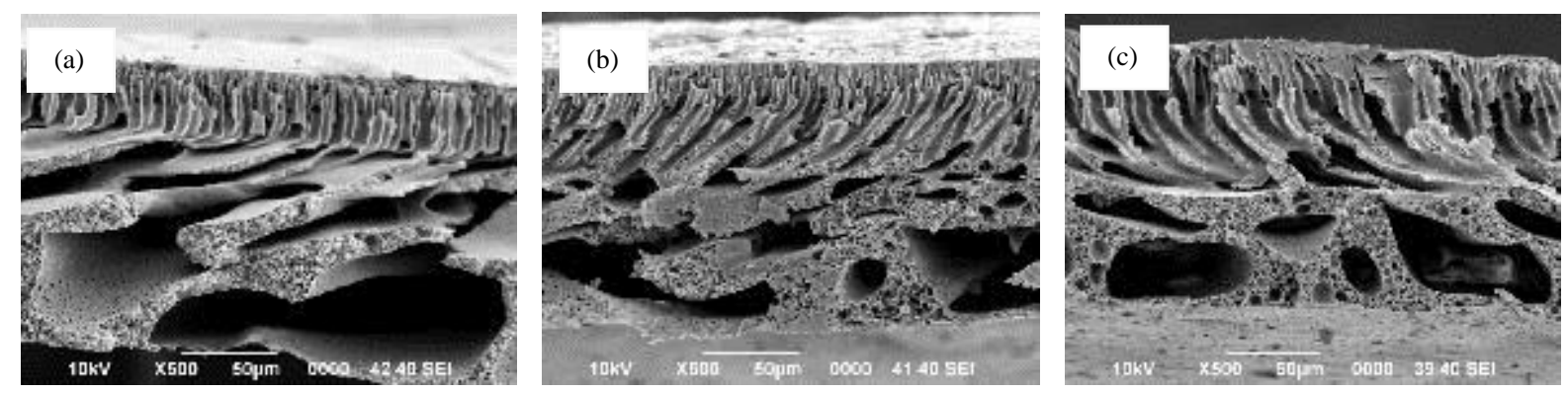

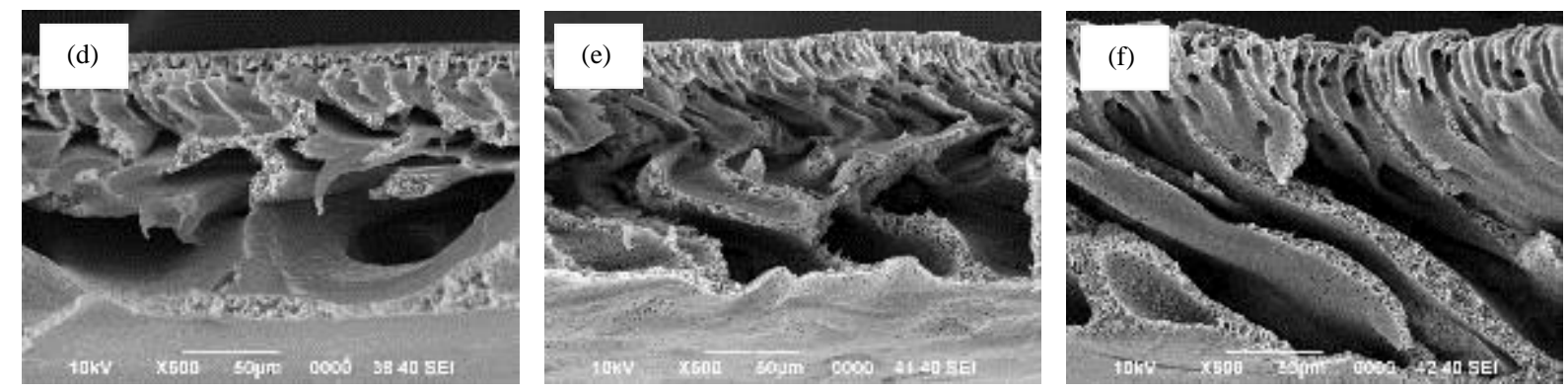

Figure 5. The cross section of (a) PES (b) PES/GO (C) PES/rGO-8h (d) PES/rGO-16h (e) PES/rGO 24h and (f) PES/rGO-32h membrane

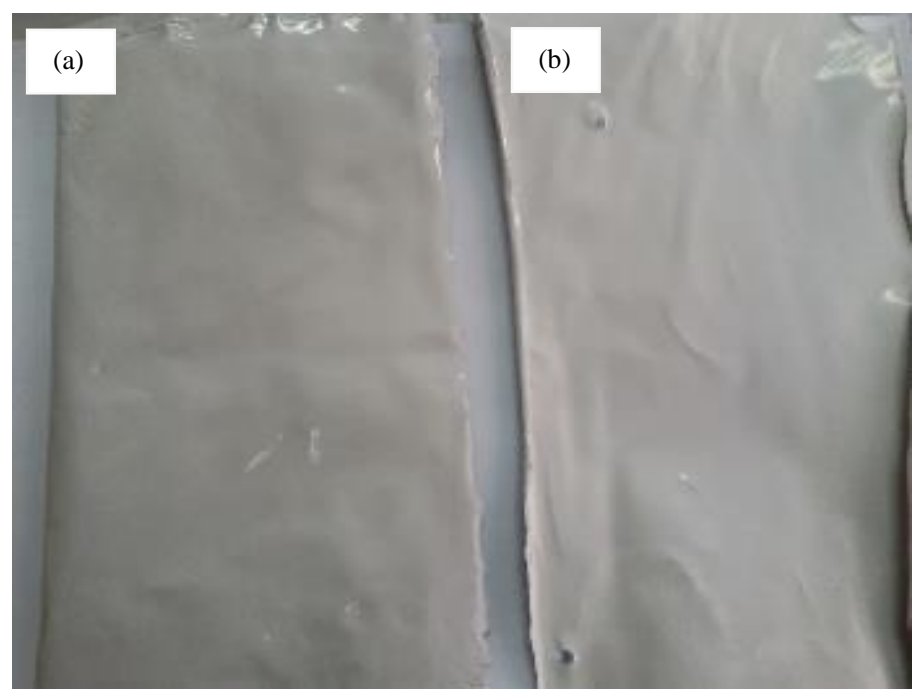

Figure 6. Comparison of (a) top (b) bottom surface of PES/GO membrane

The membrane contact angle reveals that the hydrophilicity greatly improves when rGO is used. The hydrophobic nature of rGO can interact well with hydrophobic PES. It can therefore be assumed that the addition of rGO improved the hydrophilicity of the membrane [32]. During the phase inversion process rGO migrates to the surface of the mixed matrix membranes in order to decrease the interfacial energy $[4,33]$. However, when rGO is reduced for $32 \mathrm{~h}$ there is no significant decrease in the contact angle, it increases instead. This can be explained by the fact that significant amount of oxygen functional groups have been eliminated during the reduction process [34]. Therefore, the contact angle increases from $32.99^{\circ}$ to $55.05^{\circ}$ (Table 1 ).

Table 1. Contact angle of the membrane

\begin{tabular}{lcccccc}
\hline Membrane & PES & PES/GO & $\begin{array}{c}\text { PES/rGO } \\
\mathbf{8 ~ h}\end{array}$ & $\begin{array}{c}\text { PES/rGO } \\
\mathbf{1 6} \mathbf{~ h}\end{array}$ & $\begin{array}{c}\text { PES/rGO } \\
\mathbf{2 4} \mathbf{h}\end{array}$ & $\begin{array}{c}\text { PES/rGO } \\
\mathbf{3 2 ~ \mathbf { ~ }}\end{array}$ \\
\hline Contact angle $\left({ }^{\circ} \mathrm{C}\right)$ & 69.70 & 64.45 & 34.84 & 34.20 & 32.99 & 55.05 \\
\hline
\end{tabular}

Nevertheless, in this study the pure water flux does not rely on the membrane contact angle. As illustrated in Table 1, even though the membrane contact angle of PES/GO is $64.45^{\circ}$ but it shows the highest flux, $174.29 \mathrm{~L} / \mathrm{m}^{2} \mathrm{~h}$ 
(Figure 7). With the addition of GO, the material gathered on the surface of the membrane due to hydrophilic functional groups, like hydroxyl (Figure 6) [13]. These results are in line with previous study conducted by Chai and colleague where they stated that the value of flux increases because of bigger pore size, enhancement of porosity as well as improvement in hydrophilicity [31]. Meanwhile, $40.71 \mathrm{~L} / \mathrm{m}^{2} \mathrm{~h}$ is the lowest flux achieved as the rGO was reduced at $32 \mathrm{~h}$. This may be due to blocking effect by the rGO particles. As the reduction time increased, a large amount of oxygen functional groups was eliminated which caused the rGO to be difficult to be dispersed in the polymer solution. This is because, GO and rGO possessed contrast characteristics especially in terms of dispersion. GO has a well dispersion in many solvents which includes water and alcohol due to the strong electrostatic repulsion between single layers. In contrast, because of $\pi-\pi$ stacking rGO is likely to agglomerate in solution which greatly limits the concentration of single layer solutions [34]. Thus, it blocked the membrane's surface and decreased the pure water flux as well as hydrophilicity.

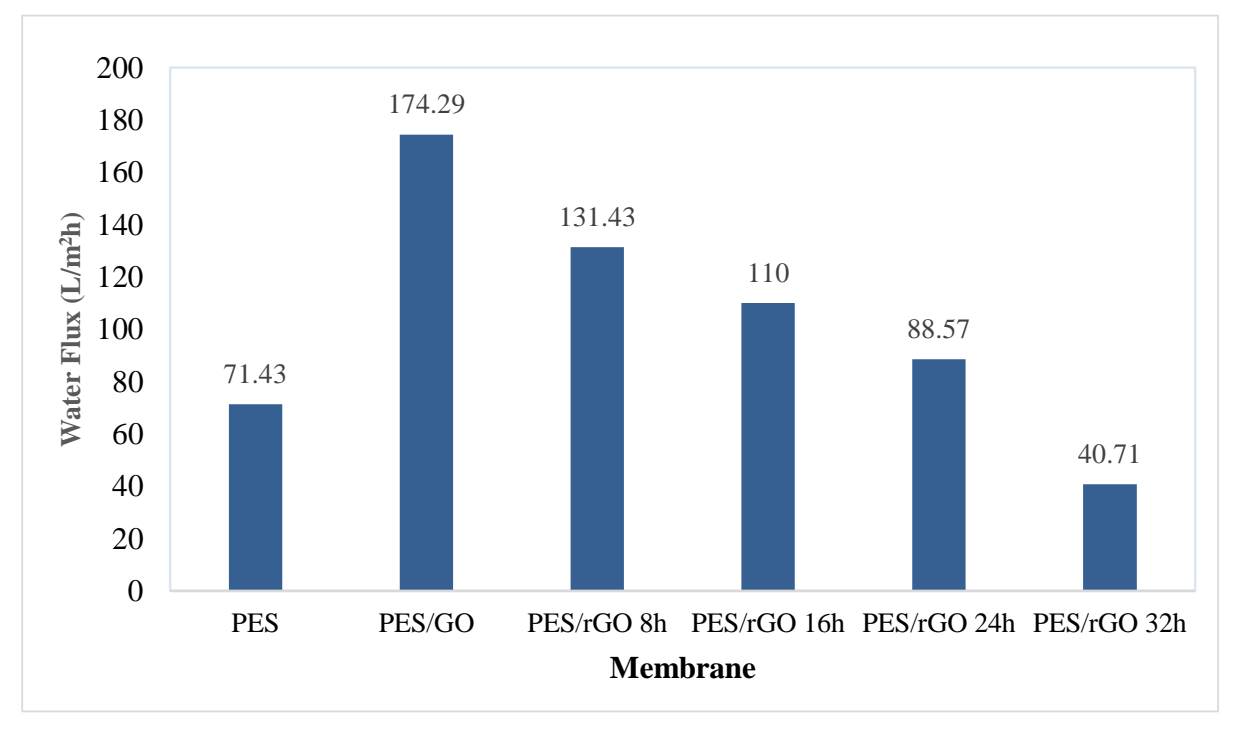

Figure 7. Pure water flux at 1 bar

\section{Conclusion}

The GO and rGO were prepared by using modified Hummer's method and chemical reduction respectively. The result showed that the carbonyl functional groups were removed after reduction process. The removal of functional groups on rGO was further confirmed using XRD as the result showed that the interlayer spacing decreased. The morphology of GO revealed that wrinkles were formed on the surface while rGO have a rougher surface due to the aggregation. The cross section of the membrane showed that all the membranes have porous structure. The contact angle of showed great improvement when rGO were introduced into the polymer matrix. Hence, due to more porous structure and increase in hydrophilicity PES/GO membrane exhibit a higher pure water flux.

\section{Acknowledgement}

We would like to express our gratitude to Faculty of Science Universiti Teknologi Malaysia for all the facilities and HiCOE research grant (4J199) from the Ministry of Higher Education of Malaysia for the financial support.

\section{References}

1. Forati, T., Atai, M., Rashidi, A. M., Imani, M. and Behnamghader, A. (2014). Physical and mechanical properties of graphene oxide/polyethersulfone nanocomposites. Polymer Advance Technology, 25:322-328.

2. Razmjou, A., Resosudarmo, A., Holmes, R. L. and Li, H. (2012). The effect of modified $\mathrm{TiO}_{2}$ nanoparticles on the polyethersulfone ultrafiltration hollow fiber membranes. Desalination, 287: 271-280. 
3. Mehrparvar, A. and Rahimpour, A. (2015) Surface modification of novel polyether sulfone amide (PESA) ultrafiltration membranes by grafting hydrophilic monomers. Journal Industry and Engineering Chemistry, 28: 359-368.

4. Zinadini, S., Zinatizadeh, A. A., Rahimi, M., Vatanpour, V., and Zangeneh, H. (2014) Preparation of a novel antifouling mixed matrix PES membrane by embedding graphene oxide nanoplates. Journal Membrane Science, 453: 292-301.

5. Peyravi, M., Rahimpour, A., Jahanshahi, M., Javadi, A. and Shockravi, A. (2012). Tailoring the surface properties of PES ultrafiltration membranes to reduce the fouling resistance using synthesized hydrophilic copolymer. Microporous Mesoporous Materials, 160:114-125.

6. Qu, P., Tang, H., Gao, Y., Zhang, L. P. and Wang, S. (2010) Polyethersulfone composite membrane blended With cellulose fibrils. BioResources, 5: 2323-2336.

7. Xiang, Q., Yu, J. and Jaroniec, M. (2012). Graphene-based semiconductor photocatalysts. Chemistry Society Reviews, 41: 782.

8. Compton, O. C. and Nguyen, S. T. (2010). Graphene oxide, highly reduced graphene oxide, and graphene : Versatile building blocks for carbon-based materials. Small, 6:711-723.

9. Kuilla, T., Bhadra, S., Yao, D. and Kim, N. H. (2010). Recent advances in graphene based polymer composites. Progress Polymer Science, 35: 1350-1375.

10. Shah, R., Kausar, A., Muhammad, B. and Shah, S. (2015). Progression from graphene and graphene oxide to high performance polymer-based nanocomposite: A review. Polymer Plastic Technology Engineering, 54:173183.

11. Ganesh, B. M., Isloor, A. M. and Ismail, A. F. (2013). Enhanced hydrophilicity and salt rejection study of graphene oxide-polysulfone mixed matrix membrane. Desalination, 313: 199-207.

12. Lee, J., Chae, H. R., Won, Y. J. and Lee, K. (2013) Graphene oxide nanoplatelets composite membrane with hydrophilic and antifouling properties for wastewater treatment. Journal Membrance Science, 448: 223-230.

13. Jin, F., Lv, W., Zhang, C. and Li, Z. (2013). High-performance ultrafiltration membranes based on polyethersulfone-graphene oxide composites. RSC Advances, 3: 21394.

14. Johnson, D.W., Dobson, B. P. and Coleman, K. S. (2015). A manufacturing perspective on graphene dispersions. Current Opinion Colloid Interface Science, 20: 367-382.

15. Mishra, S. K., Tripathi, S. N., Choudhary, V. and Gupta, B. D. (2014) SPR based fibre optic ammonia gas sensor utilizing nanocomposite film of PMMA/reduced graphene oxide prepared by in situ polymerization. Sensors Actuators, B Chemical, 199: 190-200.

16. Dahlberg, T. (2016). The first order Raman spectrum of isotope labelled nitrogen-doped reduced graphene oxide. Retrieved from http://www.diva-portal.org/smash/get/diva2:905266/FULLTEXT01 .pdf.

17. Ahmad, A. L., Abdulkarim, A. A., Ooi, B. S. and Ismail, S. (2013). Recent development in additives modifications of polyethersulfone membrane for flux enhancement. Chemical Engineering Journal, 223: 246267.

18. Pei, S. and Cheng, H. M. (2012). The reduction of graphene oxide. Carbon, 50: 3210-3228.

19. Yang, Z., Zheng, Q., Qiu, H., Li, J. and Yang, J. (2015). A simple method for the reduction of graphene oxide by sodium borohydride with $\mathrm{CaCl}_{2}$ as a catalyst. New Carbon Materials, 30: 41-47.

20. Lee, D. C., Yang, H. N., Park, S. H. and Kim, W. J. (2014). Nafion/graphene oxide composite membranes for low humidifying polymer electrolyte membrane fuel cell. Journa Membrance Science, 452: 20-28.

21. Liang, Y., Wu, D., Feng, X. and Müllen, K. (2009). Dispersion of graphene sheets in organic solvent supported by ionic interactions. Advance Materials, 21: 1679-1683.

22. Mathkar, A., Tozier, D., Cox, P. and Ong, P. (2012). Controlled, stepwise reduction and band gap manipulation of graphene oxide. Journal of Physical Chemistry Letters, 3: 986-991.

23. Deka, M. J., Baruah, U. and Chowdhury, D. (2015). Insight into electrical conductivity of graphene and functionalized graphene: Role of lateral dimension of graphene sheet. Materials Chemistry Physics, 163: 236244.

24. Silwana, B., Van der Horst, C., Iwuoha, E. and Somerset, V. (2015). Synthesis, characterisation and electrochemical evaluation of reduced graphene oxide modified antimony nanoparticles. Thin Solid Films, 592:124-134.

25. Shin, H. J., Kim, K. K., Benayad, A. and Yoon, S. M. (2009). Efficient reduction of graphite oxide by sodium borohydride and its effect on electrical conductance. Advances Functional Materials, 19: 1987-1992. 
26. Naebe, M., Wang, J., Amini, A. and Khayyam, H. (2014). Mechanical property and structure of covalent functionalised graphene/epoxy nanocomposites. Scientific Reports, 4: 1-7.

27. Hu, Y., Song, S. and Lopez-Valdivieso, A. (2015). Effects of oxidation on the defect of reduced graphene oxides in graphene preparation. Journal of Colloid Interface Sciences, 450: 68-73.

28. Kellici, S., Acord, J., Ball, J. and Reehal, H. S. (2014). A single rapid route for the synthesis of reduced graphene oxide with antibacterial activities. RSC Advances, 4: 14858.

29. Liu, S., Zeng, T. H., Hofmann, M. and Burcombe, E. (2011). Antibacterial activity of graphite, graphite oxide, graphene oxide, and reduced graphene oxide : Membrane and oxidative stress. ACS Nano, 9: 6971-6980.

30. Han, J. W. and Kim, J. (2015). Reduction of graphene oxide by resveratrol : a novel and simple biological method for the synthesis of an effective anticancer nanotherapeutic molecule. International Journal of Nanomedicine, 10: 2951-2969.

31. Chai, P. V., Mahmoudi, E., Teow, Y. H. and Mohammad, A.W. (2017). Preparation of novel polysulfone$\mathrm{Fe}_{3} \mathrm{O}_{4} / \mathrm{GO}$ mixed-matrix membrane for humic acid rejection. Journal of Water Process Engineering, 15: 83-88.

32. Ganesh, B. M., Isloor, A. M. and Ismail, A. F. (2013). Enhanced hydrophilicity and salt rejection study of graphene oxide-polysulfone mixed matrix membrane. Desalination, 313: 199-207.

33. Celik, E., Park, H., Choi, H. and Choi, H. (2011). Carbon nanotube blended polyethersulfone membranes for fouling control in water treatment. Water Research, 45: 274-282.

34. Cote, L. J., Cruz-silva, R. and Huang, J. (2009). Flash reduction and patterning of graphite oxide and its polymer composite. Journal of American Chemical Society, 131(17): 11027-11032. 